\title{
High rates of herbivory in remote northwest Australian seagrass meadows by rabbitfish and green turtles
}

\author{
Mathew A. Vanderklift ${ }^{1, *}$, Richard D. Pillans ${ }^{2}$, Marlee Hutton $^{1}$, Lisa De Wever ${ }^{1}$, \\ Gary A. Kendrick ${ }^{3}$, Andrea Zavala-Perez ${ }^{3}$, Adriana Vergés ${ }^{4}$, Ruby Garthwin ${ }^{4}$, \\ Daniel Oades ${ }^{5}$, Phillip McCarthy ${ }^{5}$, Kevin George ${ }^{5}$, Trevor Sampi ${ }^{5}$, Dwayne George ${ }^{5}$, \\ Chris Sampi ${ }^{5}$, Zac Edgar ${ }^{5}$, Kevin Dougal ${ }^{5}$, Azton Howard ${ }^{5}$ \\ ${ }^{1}$ CSIRO Oceans \& Atmosphere, Indian Ocean Marine Research Centre, Crawley, 6009 Western Australia, Australia \\ ${ }^{2}$ CSIRO Oceans \& Atmosphere, Queensland Biosciences Precinct, St. Lucia, 4067 Queensland, Australia \\ ${ }^{3}$ School of Biological Sciences and Oceans Institute, The University of Western Australia, Crawley, \\ 6009 Western Australia, Australia \\ ${ }^{4}$ School of Biological, Earth and Environmental Sciences, University of New South Wales, Sydney, \\ 2052 New South Wales, Australia \\ ${ }^{5}$ Bardi Jawi Rangers, One Arm Point, 6725 Western Australia, Australia
}

\begin{abstract}
Herbivory is a key ecological process that often determines the composition and abundance of plants. Estimates of herbivory in seagrass meadows are typically lower than those in other vegetated coastal ecosystems, but herbivory can be intense when large herbivorous vertebrates are abundant. We surveyed rates of herbivory on 2 species of tropical seagrasses (Thalassia hemprichii and Enhalus acoroides), the abundance of herbivorous vertebrates, and the diet of 2 abundant herbivorous vertebrates (the green turtle Chelonia mydas and the rabbitfish Siganus lineatus) in lagoons adjacent to remote islands off northwestern Australia. Rates of herbivory in some deployments of tethered seagrass were more than 1000 times higher than rates of production and were among the highest recorded. Consumption exceeded production in half the deployments (9 of 18). Remote underwater video revealed that $S$. lineatus was the most abundant herbivore. Stomachs of $S$. lineatus contained mostly seagrass, and models based on stable isotopes indicated that seagrass was the primary source of nutrition. Stomach contents of C. mydas were more variable, containing seagrass and macroalgae (although the sample size was low), but models based on stable isotopes indicated that seagrass was likely the primary source of nutrition. Multiple lines of evidence suggest that the high rates of herbivory on the seagrasses $T$. hemprichii and $E$. acoroides are mainly due to direct consumption by the abundant $S$. lineatus, and perhaps also C. mydas. Seagrass is the primary contributor to the nutrition of both species.
\end{abstract}

KEY WORDS: Siganus $\cdot$ Chelonia $\cdot$ Thalassia $\cdot$ Enhalus $\cdot$ Stable isotope $\cdot$ Tethering

\section{INTRODUCTION}

Herbivory is a key ecological process that often determines the composition and abundance of plants on land and in the sea. In the sea, the influence that herbivores exert tends to be more pronounced in

\footnotetext{
${ }^{*}$ Corresponding author: mat.vanderklift@csiro.au
}

coral and rocky reef ecosystems, and contemporary rates of herbivory on seagrasses are typically not high (Poore et al. 2012). However, this might reflect that many measurements have been made in temperate ecosystems, where large herbivorous vertebrates (e.g. dugongs and manatees, green turtles, parrotfish

() The authors 2021. Open Access under Creative Commons by Attribution Licence. Use, distribution and reproduction are unrestricted. Authors and original publication must be credited. 
and rabbitfish) are not usually abundant, although sea urchins and waterfowl consume large amounts of seagrass in some places (Valentine \& Heck 1999, Heck \& Valentine 2006).

Despite the generally low observed rates of herbivory on seagrasses, measurements in some places have yielded extremely high rates, sometimes exceeding production. In many seagrass ecosystems, especially near the tropics, fish are the main consumers of seagrass (Vergés et al. 2018). In tropical seagrass meadows, parrotfish are important (e.g. Kirsch et al. 2002, Unsworth et al. 2007), while in temperate meadows, other taxa tend to be more important (e.g. the sparid Sarpa salpa in the Mediterranean Sea: Prado et al. 2007). Rabbitfish (Siganus spp.) can suppress macroalgae in tropical and temperate ecosystems (e.g. Vergés et al. 2014, ZarcoPerello et al. 2017), but although many species frequently consume seagrass (e.g. El-Sayed 1994, Pitt 1997), they have not been recorded to suppress seagrass in the same way.

Many tropical regions might once have hosted higher rates of herbivory on seagrass, before populations of large herbivores such as green turtles Chelonia mydas and dugongs Dugong dugon were reduced (Heck \& Valentine 2006). Indeed, there is increasing evidence that herbivory is a strong influence on the abundance of seagrass in places where green turtles or sirenians are abundant (e.g. Kelkar et al. 2013, Lefebvre et al. 2017). In some places, herbivory by increasingly abundant green turtles has caused declines in seagrass biomass (e.g. Kelkar et al. 2013, Fourqurean et al. 2019). These declines can have cascading effects such as reduced abundances of seagrass-associated fish, and consequent reduced catches of small-scale fisheries (Arthur et al. 2013). The interactions between seagrass, green turtles and humans can be complex, because in some places, green turtles are hunted lawfully, while in others, they are protected and hunting is prohibited (Campbell 2003).

Experiments in which herbivores are excluded from places they would otherwise access (e.g. through barriers or other deterrents) provide strong inferences about the magnitude of the effect they exert (Poore et al. 2012, Vergés et al. 2018). Such experiments have demonstrated that herbivorous fish and green turtles can exert very strong effects on seagrass (e.g. Fourqurean et al. 2010, Bessey et al. 2016). A complementary experimental method, in which seagrass leaves are collected and deployed ('tethered') in meadows in a controlled way, and consumption measured, can generate useful insights about rates of herbivory relative to rates of production (e.g. Kirsch et al. 2002, Prado et al. 2007). However, neither method on its own is able to identify the species responsible for herbivory, or the importance of seagrass to their diets, so both need to be supplemented with other methods, such as video observations of consumption or evaluation of diet.

Seagrass-dwelling fishes, including herbivorous species such as parrotfish and rabbitfish, are often an important component of fisheries, especially smallscale fisheries in the Indo-Pacific (e.g. Unsworth et al. 2014, Musembi et al. 2019). These help support the fishers and their dependents through food and revenue (e.g. Unsworth et al. 2014, Quiros et al. 2018). Understanding the food resources that sustain these species will contribute to the development of sustainable practices that ensure the livelihoods of fishers are maintained.

In this study, we quantified rates of consumption of seagrass in a remote and sparsely populated region of northwestern Australia, where multiple species of large herbivores (including fishes, green turtles and dugongs) are present. We also surveyed the composition of the fauna using video, and studied the diet of 2 species considered to be likely seagrass consumers (the rabbitfish Siganus lineatus and the green turtle C. mydas) using stomach content and stable isotope analyses.

\section{MATERIALS AND METHODS}

\subsection{Study area and survey methods}

The study was done in lagoons adjacent to islands within the Bardi Jawi Indigenous Protected Area, northwestern Australia (Fig. 1). We conducted 3 surveys: October 2014, April 2015 and October 2015; not all measurements were made during each survey. In this region, the tidal range can exceed $8 \mathrm{~m}$ during spring tides (Lowe et al. 2015). The seagrasses surveyed were in lagoons enclosed by intertidal reefs; the platforms inside the reefs are above mean sea level (Gruber et al. 2017), but an elevated rim at the seaward edge ensures water is retained in the lagoons even at low tide. Generally, depths at high tide ranged from 2 to $4 \mathrm{~m}$. Water temperatures in lagoons can encompass a range of $11^{\circ} \mathrm{C}$ during a tidal cycle, reaching maxima of $\sim 38^{\circ} \mathrm{C}$ (Pedersen et al. 2016, Gruber et al. 2017). Few people live in the region; the closest town $(\sim 10 \mathrm{~km}$ distant) has a population of $<400$. Six species of seagrasses are found in the 


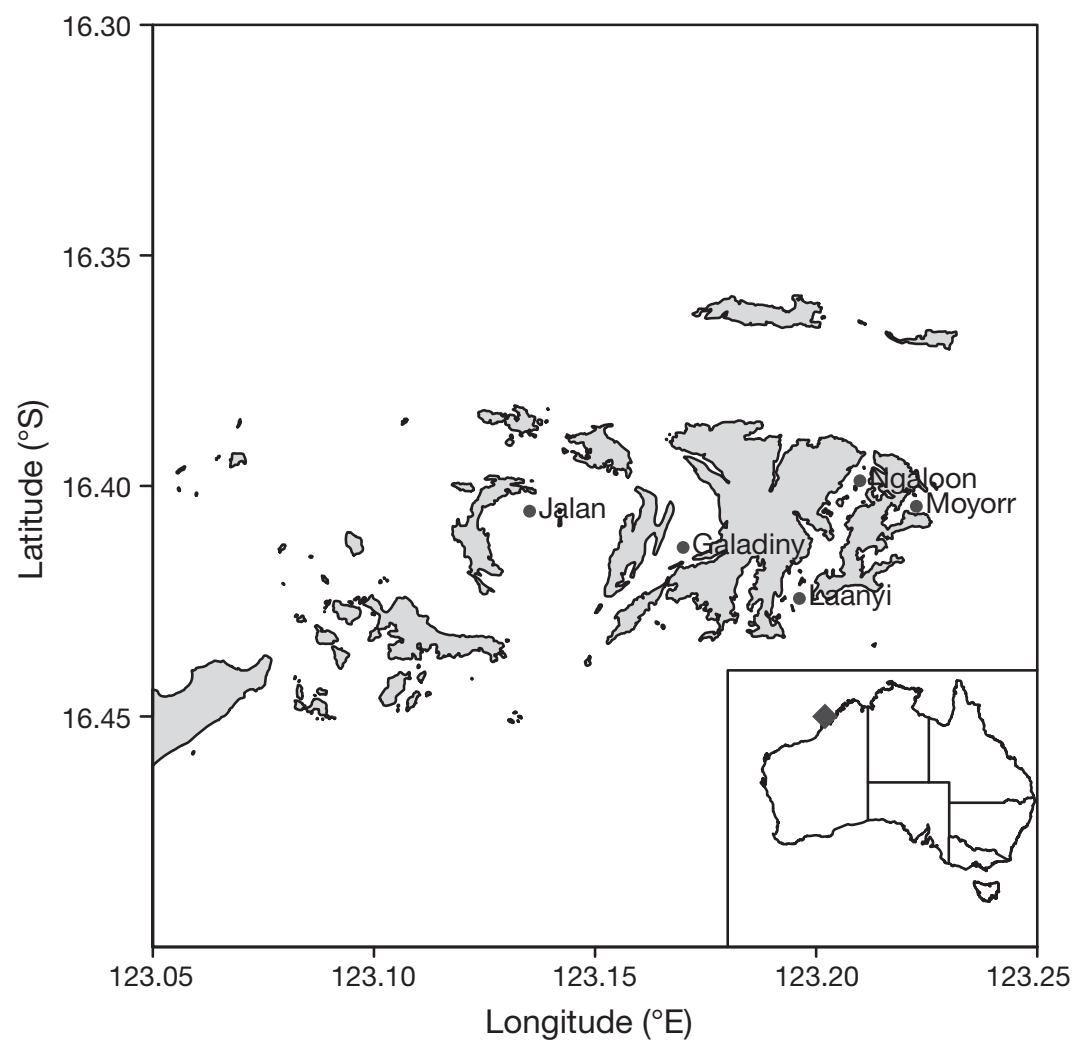

Fig. 1. Sites surveyed. Inset: general location of the study area (grey diamond) in Australia that the punched hole had moved from the ligule for each leaf. Leaf width (mm) was also measured, and growth in area $\left(\mathrm{cm}^{2}\right)$ calculated by multiplication $(\mathrm{n}=422$ measurements for Thalassia, $\mathrm{n}=89$ measurements for Enhalus).

Rates of consumption were measured through tethering experiments. In these experiments, shoots of each species were collected, the leaves were cut with scissors at the base above the leaf sheath, and leaves were separated and placed between 2 sheets of acrylic (the top sheet clear and the bottom sheet white), then photographed. Intact leaves (leaves with no evidence of herbivory or erosion) were used where possible. If no intact leaves could be found, partially grazed or eroded leaves were used after being trimmed with scissors. Shoots were then attached to a short piece of sisal rope with clothes pegs. Three shoots from a single species were attached to each rope, which was then placed in a meadow of the matching species (i.e. Thalassia lagoons; the most abundant species are Thalassia hemprichii (hereinafter Thalassia) and Enhalus acoroides (hereinafter Enhalus), which are present in patches of 1 or more species (Kendrick et al. 2017). Rock surfaces at the seaward edge of the lagoons host assemblages of macroalgae and sessile fauna (Lowe et al. 2015, Gruber et al. 2017).

\subsection{Rates of herbivory}

Rates of growth and consumption of Thalassia and Enhalus were estimated at Jalan, Laanyi and Ngaloon. Rates of growth were calculated (mm per shoot per day) using a standard hole-punch method. During each survey, three $20 \mathrm{~cm} \times 20 \mathrm{~cm}$ quadrats were haphazardly placed in meadows of each species, marked at each corner with $2.4 \mathrm{~mm}$ stainless steel reinforcing bar. All seagrass shoots within the quadrats were marked by piercing a hole just above the ligule or growing meristem. After $4 \mathrm{~d}$, all seagrass within all quadrats was completely extracted using a shovel, the sediment was rinsed off and seagrass was frozen. Seagrass was later thawed and separated into species. Growth was measured as the distance (mm) placed in Thalassia meadows, Enhalus placed in Enhalus meadows). The ropes were secured by inserting tent pegs through each end into the substrate; ropes were separated by not less than $\sim 3 \mathrm{~m}$. After $\sim 24 \mathrm{~h}$, the leaves were collected and photographed. This process was repeated on 2 separate days during each of the 3 surveys (October 2014, April 2015, October 2015) at 3 sites: Jalan, Laanyi and Ngaloon (Fig. 1). Fifteen shoots of each species were deployed on each day ( $\mathrm{n}=540$ shoots). The area of each shoot before and after deployment (in $\mathrm{cm}^{2}$ ) was calculated using image analysis software (ImageJ version 1.32). The error in area measurements between photographs was up to $\pm 10 \%$ (verified from repeat photographs of leaves with no grazing or erosion), so any change in area $<10 \%$ was considered to be $0 \%$ (see also Vanderklift et al. 2009).

Net herbivory for each location during each survey was calculated as mean daily consumption per tether (in $\mathrm{cm}^{2}$ ) divided by the mean daily growth per shoot (in $\mathrm{cm}^{2}$ ). Standard errors (SE) were calculated with error propagation following the equation:

$$
\frac{\bar{x}_{C}}{\bar{x}_{G}} \times \sqrt{\left(\frac{\mathrm{SE}_{G}}{\bar{x}_{G}}\right)^{2}+\left(\frac{\mathrm{SE}_{C}}{\bar{x}_{C}}\right)^{2}}
$$


where $\bar{x}_{C}$ and $\bar{x}_{G}$ are mean consumption and growth respectively, and $\mathrm{SE}_{C}$ and $\mathrm{SE}_{G}$ are the associated standard errors.

\subsection{Identifying potential herbivores}

Remote underwater video (RUV) cameras were deployed at Jalan and Ngaloon during April 2015. These deployments comprised 10 individual GoPro Hero 4 Silver cameras in waterproof housings deployed during daytime high tides in meadows of each of the 2 main species of seagrass, Thalassia and Enhalus, on each of $3 \mathrm{~d}$. Each camera filmed for 3-4 h during each deployment. Cameras were placed on steel camera frames; each held 2 cameras facing in opposite directions. Individual frames were separated by at least $25 \mathrm{~m}$. The maximum number of individuals observed in a single frame (MaxN) for each species of fish was quantified for $34 \mathrm{~min}$ from each camera from each deployment using EventMeasure software (SeaGIS). Video was downloaded in $17 \mathrm{~min}$ segments. Species accumulation curves were used to identify that 2 video segments (total $34 \mathrm{~min}$ ) sufficiently characterised the total number of species (R. Garthwin unpubl. data). The second and fourth video segments were analysed; the first video segment was not analysed to minimise the potential influence of the camera deployment process on fish behaviour.

\subsection{Stomach content and stable isotope analyses}

Golden-lined rabbitfish Siganus lineatus were collected by spear in October 2014 and April 2015. Ten individuals per site were collected from Jalan, Laanyi and Ngaloon in each survey. Individuals were euthanased and a small piece of dorsal muscle excised by scalpel. The stomach was removed from individuals taken in October $2014(\mathrm{n}=30)$. The stomach of each individual was separated from the rest of the digestive tract and rinsed with water. The entire stomach was used. The pieces of muscle and the stomachs were frozen $\left(-20^{\circ} \mathrm{C}\right)$.

Green turtles Chelonia mydas were captured during April $2015(\mathrm{n}=25)$ and April $2016(\mathrm{n}=29)$. Turtles were captured in the water by an experienced person jumping from a boat. Blood was extracted from turtle's necks using a $22 \mathrm{G} \times 1.5$ inch $(0.7 \times 38 \mathrm{~mm})$ needle attached to a $5 \mathrm{ml}$ syringe, and immediately frozen $\left(-20^{\circ} \mathrm{C}\right)$ and transported to the laboratory in Perth (Western Australia). Whole blood was used; whole blood yields similar stable isotope composition to red blood cells (Vanderklift et al. 2020), and was logistically easier to collect (because it required no centrifugation). Stomachs of 5 individual green turtles were donated by Bardi Jawi hunters in early 2016. A randomly selected subsample of approximately $50 \mathrm{ml}$ was taken from each stomach, because the total amount of material was large (multiple kg), and immediately frozen. All individual turtles were captured in the vicinity of the islands.

For stomach content analysis of rabbitfish and green turtles, stomach contents were spread in a $13 \mathrm{~cm}$ diameter glass dish with water set over a sheet with 60 randomly positioned dots (giving a $95 \%$ probability of recording a food type comprising $5 \%$ or more of the contents: Vanderklift et al. 2006). Stomach contents were viewed through a magnifying lamp and food items covering each dot identified to the highest taxonomic resolution possible.

Leaves of the seagrass Thalassia hemprichii, cyanobacteria growing on seagrass leaves, and thalli of the macroalgae Sargassum polycystum, Turbinaria gracilis, Laurencia spp., and Hypnea spp. were collected by hand from the same sites as other measurements and frozen $\left(-20^{\circ} \mathrm{C}\right)$.

Seagrass leaves, cyanobacteria, thalli of macroalgae, rabbitfish muscle and green turtle blood were all thawed, dried in an oven at $60^{\circ} \mathrm{C}$, and ground into a fine powder using a mixer mill (Retsch MM200). Seagrass, cyanobacteria, macroalgae, and rabbitfish muscle were all first rinsed with fresh water, and epiphytes were scraped off seagrass leaves and macroalgae thalli if present. Elemental compositions $(\% \mathrm{C}$ and $\% \mathrm{~N})$ and stable isotope compositions $\left(\delta^{13} \mathrm{C}\right.$ and $\left.\delta^{15} \mathrm{~N}\right)$ were analysed at the West Australian Biogeochemistry Centre (Perth) using a continuous-flow system consisting of a Delta V Plus isotope ratio mass spectrometer connected to a Thermo Flush elemental analyser. Data were generated in standard $\delta$-notation after multipoint normalisation to the stable isotope international reference scale (Skrzypek et al. 2010, Skrzypek 2013). International standards provided by the International Atomic Energy Agency $\left(\delta^{13} \mathrm{C}\right.$ : NBS22, USGS24, NBS19, LSVEC; $\delta^{15} \mathrm{~N}: \mathrm{N} 1, \mathrm{~N} 2$, USGS32) and internal laboratory standards (glutamic acid) were used. The uncertainty associated with the stable isotope analyses ( $\pm 1 \mathrm{SD}$ ) was not more than $0.1 \%$ for both elements.

Mixed-effects ANOVA was used to test if patterns in $\delta^{13} \mathrm{C}$ and $\delta^{15} \mathrm{~N}$ of rabbitfish muscle varied among sites (3 levels, random) or surveys (2 levels, fixed). ANOVA was also used to test whether $\delta^{13} \mathrm{C}$ and $\delta^{15} \mathrm{~N}$ of green turtle blood varied among years. These results were used to guide development of the mixing models. 


\subsection{Mixing models}

The diets of rabbitfish and green turtles were estimated by a Bayesian isotope mixing model, using prior information gained from the stomach content analyses. Analyses were done using the SIAR (Stable Isotope Analysis with R) package version 4.1 (Parnell et al. 2010). The model for green turtles used trophic enrichment factors for carbon and nitrogen of $-0.9 \pm$ $0.5 \%$ and $0.6 \pm 0.5 \%$ respectively (from data provided by Seminoff et al. 2006). The model for rabbitfish used trophic enrichment factors for carbon and nitrogen of $2.0 \pm 0.5 \%$ ond $3.8 \pm 0.5 \%$ respectively (from data provided by Hesslein et al. 1993). Standard errors were set at 0.5 to be conservative. Different trophic enrichment factors were tested; none yielded results that were substantially different. For green turtles, all seagrass identified in stomachs was Thalassia hemprichii, so this was the only seagrass species retained in models. A variety of macroalgae were observed, but most had very similar stable isotope compositions (M. Vanderklift unpubl. data), so a single group of macroalgae was included. Turbinaria spp. typically had lower $\delta^{13} \mathrm{C}$, but was not included in models because it comprised less than $1 \%$ of turtle stomach contents. For turtles, we calculated a single model, because they move widely across the study area (M. Vanderklift \& R. Pillans unpubl. data).

For rabbitfish, we calculated separate models for each site, because they are unlikely to move among lagoons, and their stomach contents showed differences among sites. PERMANOVA was used to test whether there were differences in the composition of stomach contents among sites. The stomach content data contained numerous zeros, so tests were based on Bray-Curtis dissimilarities calculated using untransformed data. Analyses were conducted using the vegan package version 2.5 in $\mathrm{R}$.

\section{RESULTS}

\subsection{Rates of herbivory}

Net rates of herbivory (as a proportion of daily production) were highly variable, ranging from 38 to $1433 \%$ for Thalassia (median $131 \%$ ) and 0 to $572 \%$ (median 145\%) for Enhalus (Fig. 2; see also Fig. S1 in the Supplement at www.int-res.com/articles/suppl/ m665p063_supp.pdf). On average, rates of consumption of tethered seagrass exceeded rates of growth of marked seagrass. Thalassia was consumed during each deployment at each location, and the rates of consumption exceeded the rates of growth during 5 of the 9 deployments (55\%). Rates of consumption of Thalassia were an order of magnitude higher than rates of growth $(>1000 \%)$ at Ngaloon during 2 deployments. Enhalus was not consumed at all during 4 of the 9 deployments, and was consumed at rates exceeding those of growth during 4 deployments.

\subsection{Identifying potential herbivores}

RUV deployments revealed that the golden-lined rabbitfish Siganus lineatus was abundant at both sites; the surgeonfish Acanthurus grammoptilus was abundant at Ngaloon (Fig. 3). Preliminary observations of stomach contents of some individuals indicated that stomachs of $S$. lineatus contained seagrass, while $A$. grammoptilus did not; subsequent investigations of diet focused on $S$. lineatus. The green turtle Chelonia mydas was also frequently observed over seagrass meadows at high tide (M. A. Vanderklift pers. obs.), and is known to eat seagrass, so its diet was also studied.

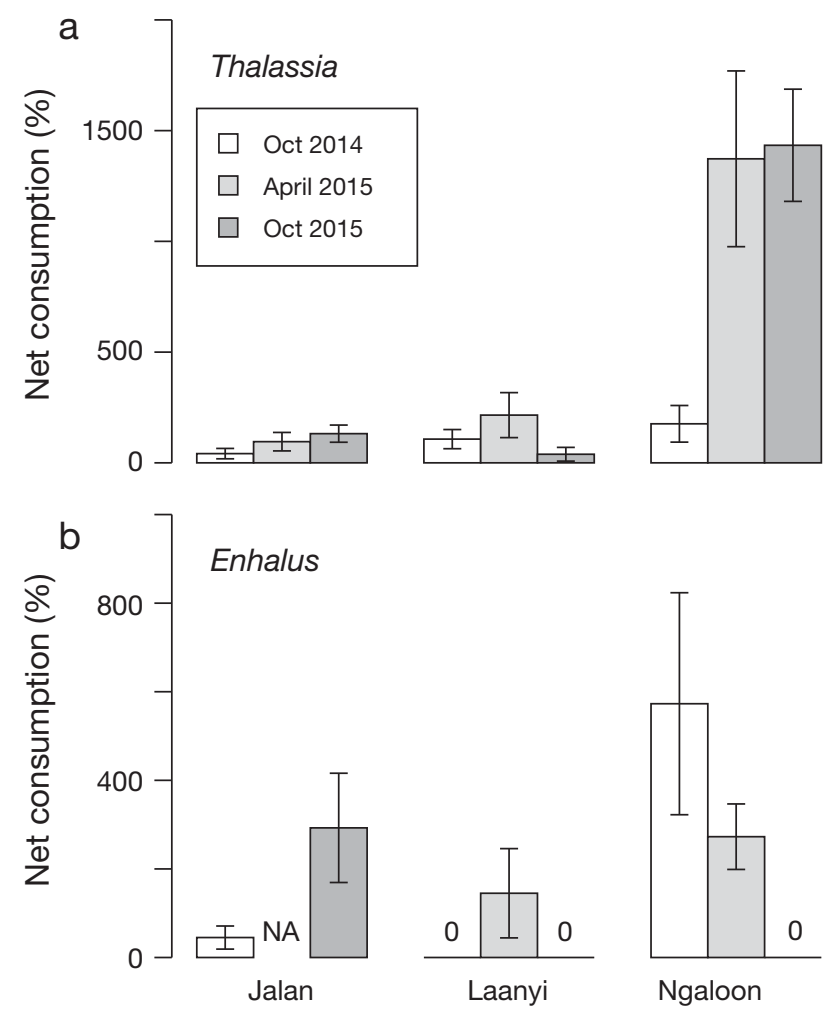

Fig. 2. Net rates of herbivory $( \pm \mathrm{SE})$ as a percentage of daily production for the seagrasses (a) Thalassia hemprichii and (b) Enhalus acoroides at 3 sites during 3 surveys. 0: no consumption of seagrass recorded on tethered seagrass during any deployment during that survey; NA: result could not be calculated due to missing data. Note the different $y$-axis scales 

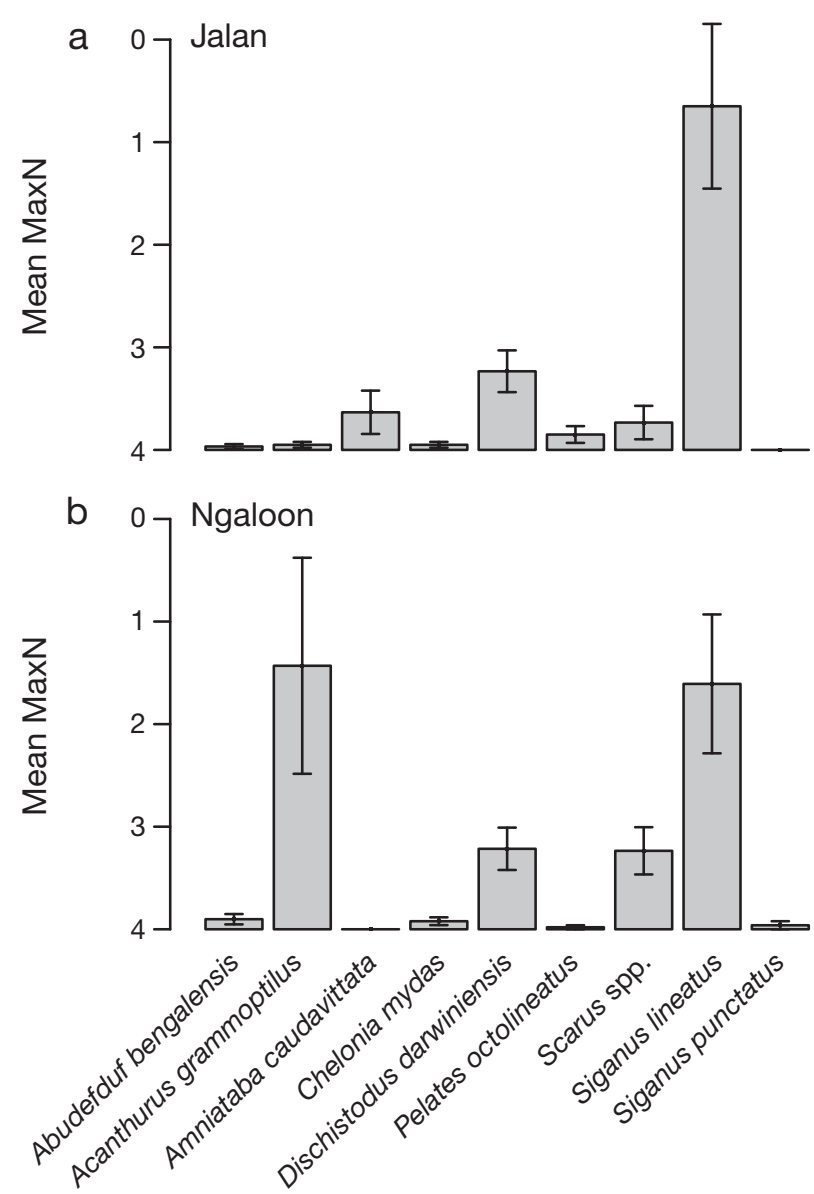

Fig. 3. Mean $( \pm \mathrm{SE})$ of the maximum number of individuals observed in a single frame (MaxN) of the most abundant species of herbivorous fish (plus the green sea turtle Chelonia mydas) recorded from remote underwater video deployments in seagrass meadows during April 2016 at (a) Jalan and (b) Ngaloon

\subsection{Stomach contents}

Of the 5 individual green turtles C. mydas for which stomach contents were quantified, the stomachs of 3 individuals comprised mostly seagrass $T$. hemprichii (80-100\%: data not shown). The stomach of the other 2 individuals contained exclusively $(100 \%)$ macroalgae of various kinds. No animal mat- ter was recorded in the stomach of any of the 5 individuals.

The stomach contents of golden-lined rabbitfish $S$. lineatus varied significantly among sites $(F=3.07, \mathrm{p}=$ 0.02) (Table S1 in the Supplement), but at all sites, seagrass (primarily $T$. hemprichii) comprised the bulk of the stomach contents (Table 1). At Jalan, a higher proportion (15\%) of cyanobacteria was found in the stomachs, while at Laanyi and Ngaloon, proportionally more red algae was observed.

\subsection{Stable isotope analysis}

$\delta^{13} \mathrm{C}$ of primary producers encompassed a wide range, with substantial overlap - especially between seagrass and macroalgae (Fig. 4). In particular, Thalassia (range: -24.9 to $-9.3 \%$; mean $-14.4 \%$ ), and brown macroalgae (range: -23.6 to $-8.4 \%$; mean $-15.5 \%$ ) yielded wide values with substantial overlap, while red macroalgae (range: -18.9 to $-15.7 \%$; mean $-17.1 \%$ ) yielded a much narrower range. Cyanobacteria also fell within the range of Thalassia and brown macroalgae (range: -20.5 to $-8.3 \%$; mean $-15.0 \%$ ). Within the macroalgae, there were some separation among genera, such as between Sargassum (range: -23.7 to $-13.8 \%$ ) and Turbinaria (range: -12.8 to $-9.2 \%$ ), but $\delta^{13} \mathrm{C}$ of most taxa overlapped.

$\delta^{15} \mathrm{~N}$ of primary producers encompassed a narrower range (Fig. 4), with some overlap between Thalassia (range: 0.4 to $6.0 \%$; mean $3.1 \%$ ) and brown macroalgae (range: 1.3 to $6.1 \%$; mean $3.6 \%$ ); the range for red macroalgae tended to be narrower (range: 2.6 to $4.3 \%$; mean $3.4 \%$ ), while on average, $\delta^{15} \mathrm{~N}$ of cyanobacteria tended to be lower (range: 0.1 to $2.7 \%$; mean $1.2 \%$ ).

$\delta^{13} \mathrm{C}$ and $\delta^{15} \mathrm{~N}$ of $C$. mydas blood did not differ substantially between 2015 and 2016 (p > 0.2 in each case), so data from different years were pooled for all subsequent analyses. $\delta^{13} \mathrm{C}$ spanned a wide range ( -20.6 to $-7.9 \%$ : Fig. 4$)$, but most data were from -11 to $-8 \%$ (Fig. S2 in the Supplement). The range in $\delta^{15} \mathrm{~N}$ was smaller (4.2 to $8.9 \%$ : Fig. 4 ) and tended to be between 4 and $7 \%$ (Fig. S2).

Table 1. Relative abundance of foods observed in the stomachs of the rabbitfish Siganus lineatus. Data are mean relative abundance (out of a maximum possible value of 60 dots), $\pm S E, n=10$ in each case

\begin{tabular}{|lccccccc|}
\hline Site & Seagrass & Mangrove root & Red algae & Brown algae & Green algae & Cyanobacteria & Other \\
\hline Jalan & $39.6 \pm 6.4$ & $0.3 \pm 0.2$ & $3.2 \pm 2.6$ & $0.2 \pm 0.2$ & $0.8 \pm 0.8$ & $15.4 \pm 6.8$ & $0.5 \pm 0.5$ \\
Laanyi & $39.9 \pm 4.2$ & 0.0 & $14.1 \pm 3.5$ & $0.2 \pm 0.2$ & 0.0 & $5.8 \pm 3.9$ \\
Ngaloon & $48.5 \pm 2.1$ & 0.0 & $10.1 \pm 2.3$ & $0.2 \pm 0.2$ & 0.0 & 0.0 & $1.1 \pm 1.0$ \\
\hline
\end{tabular}




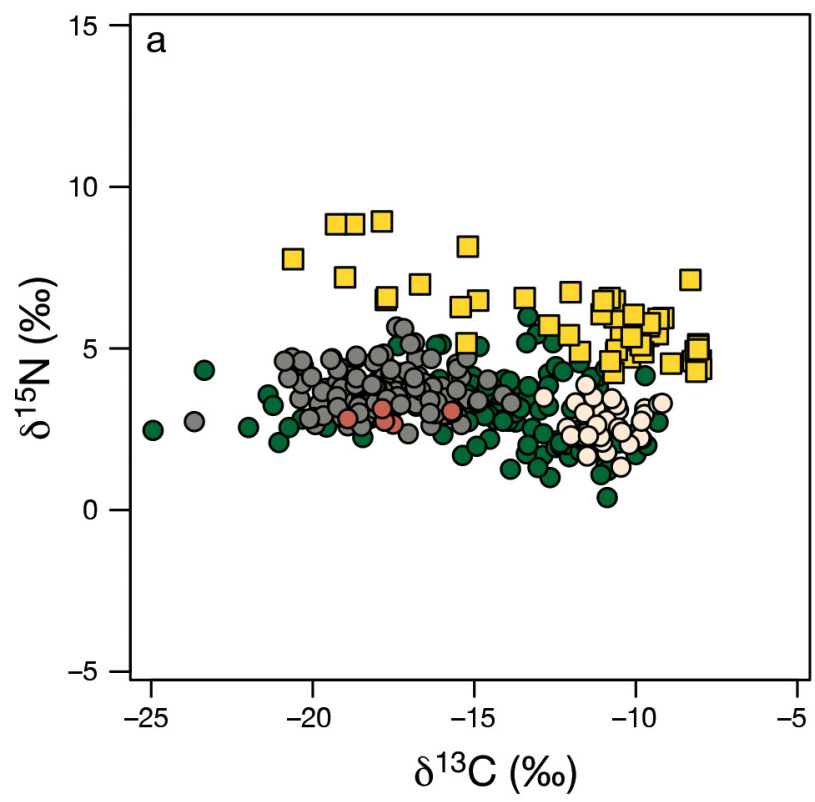

- Thalassia hemprichii

- Sargassum polycystum

- Turbinaria gracilis

- Laurencia spp.

- Hypnea spp.

- Cyanobacteria

- Chelonia mydas

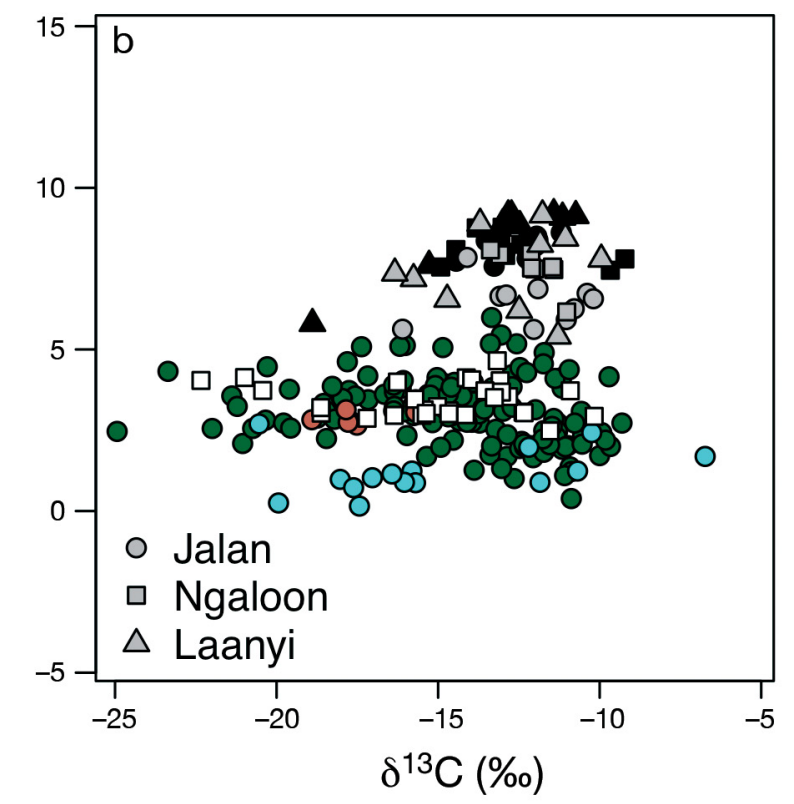

- Siganus lineatus (October 2014)

- Siganus lineatus (April 2015) - Siganus lineatus stomach contents

Fig. 4. Individual measurements of $\delta^{13} \mathrm{C}$ and $\delta^{15} \mathrm{~N}$ of (a) green turtle Chelonia mydas blood and benthic primary producers likely to be consumed by C. mydas and (b) rabbitfish Siganus lineatus muscle tissue and benthic primary producers likely to be consumed by $S$. lineatus. Individual measurements of $\delta^{13} \mathrm{C}$ and $\delta^{15} \mathrm{~N}$ of $S$. lineatus collected from different sites are denoted by different symbols

$\delta^{13} \mathrm{C}$ of $S$. lineatus spanned a narrower range than that of C. mydas (-18.9 to $-9.2 \%$ ), and the range in $\delta^{15} \mathrm{~N}$ was relatively low (5.4 to $9.2 \%$ ) (Fig. 4 ). Stomach contents of $S$. lineatus yielded a wider range of $\delta^{13} \mathrm{C}\left(-22.3\right.$ to $-10.2 \%$ ), while $\delta^{15} \mathrm{~N}$ tended to be much lower, with a narrower range ( 2.5 to $4.7 \%$ ). The $\delta^{15} \mathrm{~N}$, but not $\delta^{13} \mathrm{C}$, of $S$. lineatus muscle varied significantly among sites $\left(p=0.01\right.$ for $\delta^{15} \mathrm{~N}, \mathrm{p}=0.49$ for $\delta^{13} \mathrm{C}$ ) (Table S2 in the Supplement); $\delta^{15} \mathrm{~N}$ was significantly lower in April $2015(7.2 \pm 0.19 \%$ o) than in October $2014(8.2 \pm 0.13 \%)(\mathrm{p}<0.001)$. Mixing models considered $S$. lineatus collected at different sites separately, but combined the data from the 2 surveys.

The mixing model for C. mydas indicated that seagrass was most likely the main diet source (Fig. 5), comprising $77-100 \%$ of diet (95\% confidence intervals), while macroalgae was probably less important overall (95\% confidence intervals: 0-23\%). This reflects that $\delta^{13} \mathrm{C}$ of most individual turtles tended to fall in a range somewhat higher than that of most macroalgae (Fig. S2).

Mixing models for $S$. lineatus indicated that diet at all sites was likely dominated by seagrass (Fig. 5), and the ranges of plausible contributions at all sites were similar (95\% confidence intervals: $40-77 \%$ at Jalan, $45-86 \%$ at Ngaloon, 33-83\% at Laanyi). Macroalgae was the likely next most consumed diet at all sites, while the likely contributions of cyanobacteria were relatively low.

\section{DISCUSSION}

We found some of the highest rates of herbivory recorded for seagrasses globally, but they were temporally and spatially very variable. Video showed that herbivorous fish, especially the goldenlined rabbitfish Siganus lineatus (hereafter Siganus), were abundant at high tide. Green turtles Chelonia mydas (hereafter Chelonia) were regularly observed entering lagoons as the tide rose during the research, but were infrequently observed using video. Stomachs of Siganus and Chelonia contained high proportions of seagrass, and mixing models based on stable isotope composition suggested that seagrass was the major food source and comprised the majority of nutrition for both taxa. 

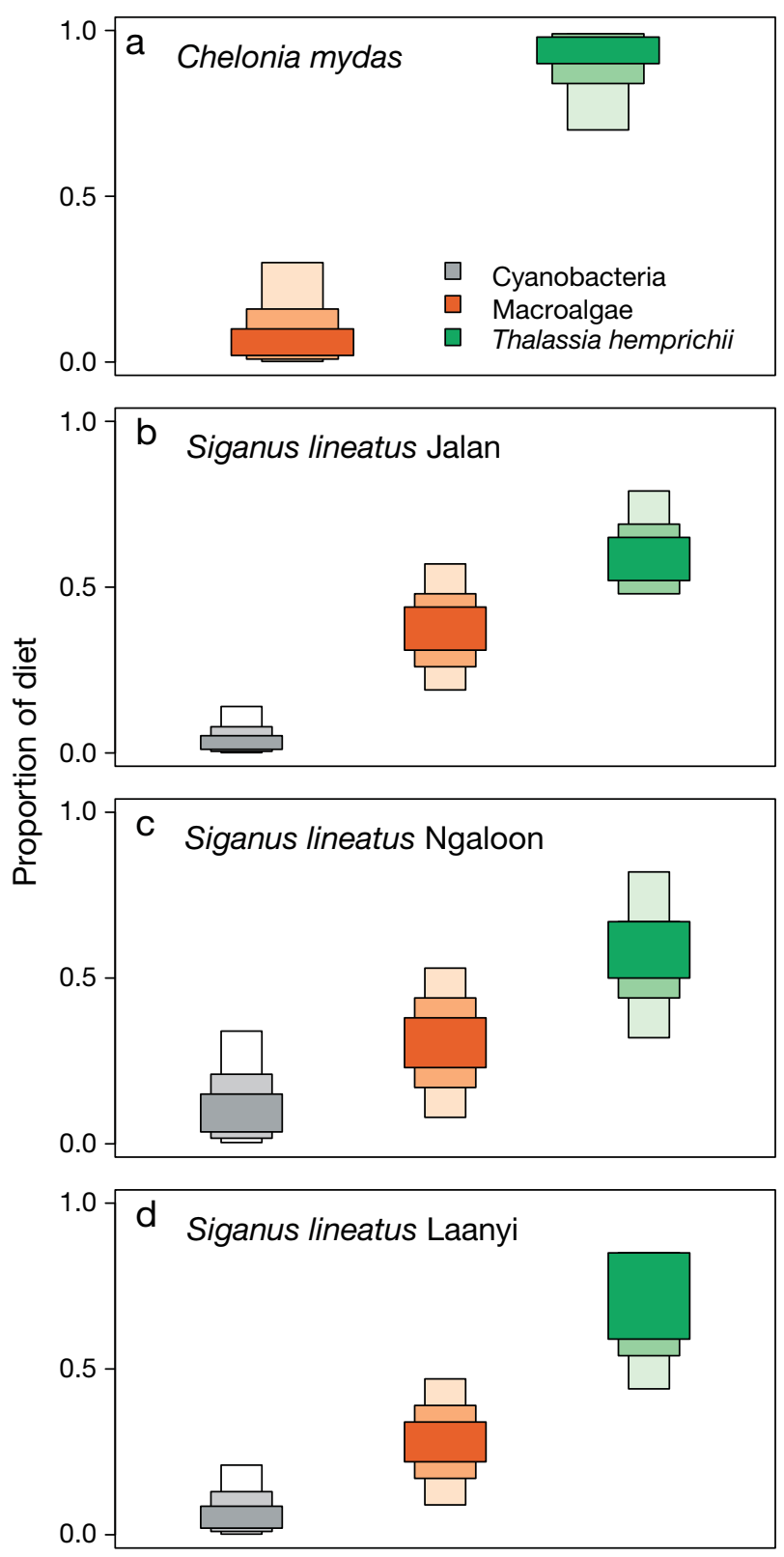

Fig. 5. Boxplots showing likely proportions of cyanobacteria, macroalgae and seagrass (Thalassia hemprichii) consumed by (a) green turtles Chelonia mydas and (b-d) golden-lined rabbitfish Siganus lineatus from 3 different sites. Plots show the 50, 75, and $95 \%$ probabilities for each potential food source, generated by stable isotope mixing models

The rates of consumption of seagrass we measured were among the highest recorded anywhere in the world (Heck \& Valentine 2006). Using tethering experiments, we estimate that consumption rates frequently exceeded growth rates. Rates varied considerably among deployments on different days, in different years and at different sites, but the median rate of consumption of Thalassia hemprichii was
$131 \%$ of daily production, and in some deployments exceeded $1000 \%$. The median rate of consumption of Enhalus acoroides was $145 \%$ of daily production, and in some deployments exceeded $500 \%$. Unsworth et al. (2007) recorded similar rates of grazing in Sulawesi, but the pattern was reversed - they recorded higher rates of grazing on Enhalus (average $787 \%$ of daily production) than on Thalassia (average $64 \%$ of daily production). The observations that rates of consumption exceed rates of production appears incongruent with the presence of dense seagrass meadows. However, we observed that grazing rates were not uniformly high, and even in Thalassia meadows, there were times and places for which production exceeded consumption. It is likely that spatial and temporal patchiness in activities of herbivores compensates for the episodic high grazing by providing sufficient time for seagrass to grow. The tides in the region are semi-diurnal (Lowe et al. 2015); Siganus and Chelonia were mostly absent during low tide, and only appeared to be active around high tide (authors' pers. obs.). These observations, together with measurements showing that seagrasses are able to photosynthesise even during the high water temperatures experienced in the lagoon during daytime high tide (Pedersen et al. 2016), suggest that there are periods spanning several hours each day when production exceeds consumption. We do not know if Siganus or Chelonia feed during night-time high tides, but studies elsewhere have shown that they can (Taquet et al. 2006, Fox \& Bellwood 2011).

It is also possible that the balance between growth and herbivory is different from November to March. Our surveys were done outside the wet season; in the Kimberley, the wet season tends to occur from November to April. We surveyed in April (just after the wet season) and late October or early November (just before the wet season), because working in the wet season presents logistical difficulties. Kendrick et al. (2017) suggested that growth of Enhalus (but probably not Thalassia) might be higher during the wet season, although this was based on very limited data from Jalan. We have no data on rates of herbivory, but one line of inference suggests that herbivory by Siganus might not be higher during the wet season: Siganus tend to contain internal fat deposits during the dry season (April to October: Rouja et al. 2003), a feature which can reflect more active feeding prior to spawning (Wootton 1990), which would be consistent with an inference that feeding rates are not higher in the wet season.

Spatial variation in consumption by Siganus is also likely due to its tendency to forage in schools. We 
observed that schools of Siganus move onto seagrass beds with the rising tide (a behaviour also observed by $S$. lineatus at Green Island in northeastern Australia: Pitt 1997), and the daily area encompassed by individuals foraging in schools is a small proportion of its total range (Fox \& Bellwood 2011). It is also plausible that the method we used yielded higher rates of herbivory than normally occur; if the tethering apparatus was visible to herbivores, or the leaves themselves were noticeably different, it might have acted as an attractant that would tend to inflate the estimates (Kirsch et al. 2002).

Unsworth et al. (2007) found similarly high rates of herbivory in Sulawesi using similar methods, observing that scarids were probably the major herbivore. Kirsch et al. (2002) also found that rates of consumption at times exceeded rates of production in the Caribbean, and that scarids were probably the major herbivore. It is unlikely that scarids are significant herbivores in the seagrass meadows we studied, because they were not abundant and were not observed biting at seagrass (R. Garthwin unpubl. data).

The fish assemblage observed was broadly consistent with that of fish faunas in other tropical ecosystems, particularly Indo-Pacific ecosystems dominated by Thalassia and Enhalus. Siganids (rabbitfish) are typically among the most common herbivores, and can be among the most abundant of all fishes (Blaber et al. 1992, Gullstrom et al. 2002). Scarids (parrotfish) can also be abundant (Gullstrom et al. 2008), particularly in Caribbean seagrass meadows (Valentine et al. 2007). Few studies have found that acanthurids (surgeonfish) are abundant in seagrass meadows. Our observations of Acanthurus grammoptilus at Ngaloon might be due to the close proximity of algae-dominated habitat nearby, although it is possible that they feed on epiphytes.

It is likely that seagrass contributes the majority of nutrition for Siganus and Chelonia. Two lines of evidence support this inference: direct observations of stomach contents, and stable isotope mixing models. For Siganus, both lines of evidence yielded very similar results. Stomachs tended to contain large proportions of seagrass at all 3 sites and during both surveys. On average, more than two-thirds of the stomach contents (by volume) was comprised of seagrass-mostly Thalassia. Stable isotope mixing models supported this, with the $95 \%$ confidence intervals for the proportion of seagrass consumed being $40-77 \%$ at Jalan, $45-86 \%$ at Ngaloon, and $33-83 \%$ at Laanyi. Other studies of the diet of $S$. lineatus inhabiting seagrass meadows have founds similar results (El-Sayed 1994, Pitt 1997). Like our study, Pitt (1997) also found that adult S. lineatus consumed cyanobacteria and macroalgae; in our study area, cyanobacteria grows epiphytically on seagrass leaves or as mats on sand, while macroalgae grows on rocky surfaces at the edge of the lagoon. Both contributed relatively less to the Siganus diet than seagrass, and cyanobacteria likely contributes relatively little.

Results for green turtles were more complex. The number of stomachs obtained was low $(\mathrm{n}=5)$, because of the ethical restrictions involved in sacrificing turtles for diet analysis and the consequent use of samples donated by hunters. Of the 5 stomachs examined, 3 were dominated by seagrass (Thalassia); 1 of these contained only seagrass, while 2 had small amounts of macroalgae. The other 2 stomachs contained a mixture of different macroalgae. Patterns in stable isotope composition of blood also indicated the possibility that diet varied among individuals, because there was a wide range in $\delta^{13} \mathrm{C}$. However, mixing models indicated that seagrass was likely the main diet, with $95 \%$ confidence intervals of the contribution of seagrass to diet being $77-100 \%$.

The findings for the diet of green turtles are broadly consistent with those of other studies, which have found that they are generally herbivorous and can consume a range of seagrasses and macroalgae (Bjorndal 1997). It is possible that there is some individual-level specialisation, with at least some individuals consuming very specific diets over a long period (Vander Zanden et al. 2013). Both Chelonia and Siganus are consumed by the Bardi Jawi people, who have rights to, and responsibility for, management of the Indigenous Protected Area that the islands are within. Siganus are consumed during the dry season (April to October) when they are observed to contain internal fat reserves (Rouja 1998) an insight that might suggest seasonal differences in feeding ecology and nutrition (as well as reproductive ecology).

Multiple lines of evidence suggest that the high rates of herbivory on the seagrasses Thalassia and Enhalus are likely due to direct consumption by the abundant golden-lined rabbitfish $S$. lineatus and the green turtle C. mydas. Seagrass is the primary contributor to the nutrition of both species.

Acknowledgements. This study was done with the assistance of many people. We thank Doug Bearham, James McLaughlin, Monique Grol, Emy Guilbault, Lucie Chovrelat, Melanie Orr and Jessica Stubbs for their help in the field. We are grateful to the Bardi Jawi Traditional Owners 
for their permission to work in their sea country and we thank the Kimberley Marine Research Station staff, in particular James Brown, for their support. The study was financially supported by funding provided through the Western Australian Marine Science Institution. Animal handling procedures were conducted according to permit 2015-02 issued by the CSIRO Wildlife and Large Animal Ethics Committee.

\section{LITERATURE CITED}

Arthur R, Kelkar N, Alcoverro T, Madhusudan MD (2013) Complex ecological pathways underlie perceptions of conflict between green turtles and fishers in the Lakshadweep Islands. Biol Conserv 167:25-34

Bessey C, Heithaus MR, Fourqurean JW, Gastrich KR, Burkholder DA (2016) Importance of teleost macrograzers to seagrass composition in a subtropical ecosystem with abundant populations of megagrazers and predators. Mar Ecol Prog Ser 553:81-92

Bjorndal KA (1997) Foraging ecology and nutrition of sea turtles. In: Lutz PL, Musick JA (eds) The biology of sea turtles. CRC Press, Boca Raton, FL, p 199-231

Blaber SJM, Brewer DT, Salini JP, Kerr JD, Conacher C (1992) Species composition and biomasses of fishes in tropical seagrasses at Groote Eylandt, northern Australia. Estuar Coast Shelf Sci 35:605-620

Campbell LM (2003) Contemporary culture, use, and conservation of sea turtles. In: Lutz PL, Musick JA, Wyneken J (eds) The biology of sea turtles, Vol II. CRC Press, Boca Raton, FL, p 307-338

El-Sayed AM (1994) Feeding habits of rabbitfishes, Siganus canaliculatus and Siganus javus fingerlings from the Arabian Gulf waters of Qatar. Indian J Geo-Mar Sci 23: 112-114

Fourqurean JW, Manuel S, Coates KA, Kenworthy WJ, Smith SR (2010) Effects of excluding sea turtle herbivores from a seagrass bed: Overgrazing may have led to loss of seagrass meadows in Bermuda. Mar Ecol Prog Ser 419:223-232

Fourqurean JW, Manuel SA, Coates KA, Massey SC, Kenworthy WJ (2019) Decadal monitoring in Bermuda shows a widespread loss of seagrasses attributable to overgrazing by the green sea turtle Chelonia mydas. Estuar Coasts 42:1524-1540

Fox RJ, Bellwood DR (2011) Unconstrained by the clock? Plasticity of diel activity rhythm in a tropical reef fish, Siganus lineatus. Funct Ecol 25:1096-1105

Gruber RK, Lowe RJ, Falter JL (2017) Metabolism of a tidedominated reef platform subject to extreme diel temperature and oxygen variations. Limnol Oceanogr 62:1701-1717

*Gullström M, de la Torre-Castro M, Bandeira SO, Björk M and others (2002) Seagrass ecosystems in the Western Indian Ocean. Ambio 31:588-596

* Gullström M, Bodin M, Nilsson PG, Öhman MC (2008) Seagrass structural complexity and landscape configuration as determinants of tropical fish assemblage composition. Mar Ecol Prog Ser 363:241-255

Heck KL Jr, Valentine JF (2006) Plant-herbivore interactions in seagrass meadows. J Exp Mar Biol Ecol 330:420-436

Hesslein RH, Hallard KA, Ramlal P (1993) Replacement of sulfur, carbon, and nitrogen in tissue of growing broad whitefish (Coregonus nasus) in response to a change in diet traced by $\delta^{34} \mathrm{~S}, \delta^{13} \mathrm{C}$, and $\delta^{15} \mathrm{~N}$. Can J Fish Aquat Sci 50:2071-2076
Kelkar N, Arthur R, Marba N, Alcoverro T (2013) Green turtle herbivory dominates the fate of seagrass primary production in the Lakshadweep islands (Indian Ocean). Mar Ecol Prog Ser 485:235-243

Kendrick GA, Vanderklift M, Bearham D, McLaughlin J and others (2017) Benthic primary productivity: production and herbivory of seagrasses, macroalgae and microalgae. Western Australian Marine Science Institution, Perth

K Kirsch KD, Valentine JF, Heck KL Jr (2002) Parrotfish grazing on turtlegrass Thalassia testudinum: evidence for the importance of seagrass consumption in food web dynamics of the Florida Keys National Marine Sanctuary. Mar Ecol Prog Ser 227:71-85

* Lefebvre LW, Provancha JA, Slone DH, Kenworthy WJ (2017) Manatee grazing impacts on a mixed species seagrass bed. Mar Ecol Prog Ser 564:29-45

พ Lowe RJ, Leon AS, Symonds G, Falter JL, Gruber R (2015) The intertidal hydraulics of tide-dominated reef platforms. J Geophys Res Oceans 120:4845-4868

* Musembi P, Fulanda B, Kairo J, Githaiga M (2019) Species composition, abundance and fishing methods of smallscale fisheries in the seagrass meadows of Gazi Bay, Kenya. J Indian Ocean Reg 15:139-156

* Parnell AC, Inger R, Bearhop S, Jackson AL (2010) Source partitioning using stable isotopes: coping with too much variation. PLOS ONE 5:e9672

* Pedersen O, Colmer TD, Borum J, Zavala-Perez A, Kendrick GA (2016) Heat stress of two tropical seagrass species during low tides - impact on underwater net photosynthesis, dark respiration and diel in situ internal aeration. New Phytol 210:1207-1218

Pitt JM (1997) The feeding ecology of rabbitfish (Siganidae) at Green Island reef: ontogenetic and interspecific differences in diet, morphology and habitat utilisation. PhD thesis, James Cook University, Townsville

P Poore AGB, Campbell AH, Coleman RA, Edgar GJ and others (2012) Global patterns in the impact of marine herbivores on benthic primary producers. Ecol Lett 15: 912-922

* Prado P, Tomas F, Alcoverro T, Romero J (2007) Extensive direct measurements of Posidonia oceanica defoliation confirm the importance of herbivory in temperate seagrass meadows. Mar Ecol Prog Ser 340:63-71

* Quiros TEAL, Beck MW, Araw A, Croll DA, Tershy B (2018) Small-scale seagrass fisheries can reduce social vulnerability: a comparative case study. Ocean Coast Manage 157:56-67

Rouja PM (1998) Fishing for culture: toward an Aboriginal theory of marine resource use among the Bardi Aborigines of One Arm Point, Western Australia. PhD thesis, Durham University

* Rouja P, Dewailly E, Blanchet C, the Bardi Community (2003) Fat, fishing patterns, and health among the Bardi people of north western Australia. Lipids 38:399-405

Seminoff JA, Jones TT, Eguchi T, Jones DR, Dutton PH (2006) Stable isotope discrimination $\left(\delta^{13} \mathrm{C}\right.$ and $\left.\delta^{15} \mathrm{~N}\right)$ between soft tissues of the green sea turtle Chelonia mydas and its diet. Mar Ecol Prog Ser 308:271-278

* Skrzypek G (2013) Normalization procedures and reference material selection in stable HCNOS isotope analyses: an overview. Anal Bioanal Chem 405:2815-2823

* Skrzypek G, Sadler R, Paul D (2010) Error propagation in normalization of stable isotope data: a Monte Carlo analysis. Rapid Commun Mass Spectrom 24:2697-2705 
Taquet C, Taquet M, Dempster T, Soria M, Ciccione S, Roos D, Dagorn L (2006) Foraging of the green sea turtle Chelonia mydas on seagrass beds at Mayotte Island (Indian Ocean), determined by acoustic transmitters. Mar Ecol Prog Ser 306:295-302

Unsworth RKF, Taylor JD, Powell A, Bell JJ, Smith DJ (2007) The contribution of scarid herbivory to seagrass ecosystem dynamics in the Indo-Pacific. Estuar Coast Shelf Sci 74:53-62

Unsworth RKF, Hinder SL, Bodger OG, Cullen-Unsworth LC (2014) Food supply depends on seagrass meadows in the coral triangle. Environ Res Lett 9:094005

Valentine JF, Heck KL Jr (1999) Seagrass herbivory: evidence for the continued grazing of marine grasses. Mar Ecol Prog Ser 176:291-302

Valentine JF, Heck KL Jr, Blackmon D, Goecker ME and others (2007) Food web interactions along seagrass-coral reef boundaries: effects of piscivore reductions on crosshabitat energy exchange. Mar Ecol Prog Ser 333:37-50

Vanderklift MA, Kendrick GA, Smit AJ (2006) Differences in trophic position among sympatric sea urchin species. Estuar Coast Shelf Sci 66:291-297

Vanderklift MA, Lavery PS, Waddington KI (2009) Intensity

Editorial responsibility: Morten Pedersen,

Roskilde, Denmark

Reviewed by: 3 anonymous referees of herbivory on kelp by fish and sea urchins differs between inshore and offshore reefs. Mar Ecol Prog Ser 376:203-211

* Vanderklift MA, Pillans RD, Robson NA, Skrzypek G, Stubbs JL, Tucker AD (2020) Comparisons of stable isotope composition among tissues of green turtles. Rapid Commun Mass Spectrom 34:e8839

Vander Zanden HB, Bjorndal KA, Bolten AB (2013) Temporal consistency and individual specialization in resource use by green turtles in successive life stages. Oecologia 173:767-777

* Vergés A, Tomas F, Cebrian E, Ballesteros E and others (2014) Tropical rabbitfish and the deforestation of a warming temperate sea. J Ecol 102:1518-1527

*Vergés A, Doropoulos C, Czarnik R, McMahon K, Llonch N, Poore AGB (2018) Latitudinal variation in seagrass herbivory: global patterns and explanatory mechanisms. Glob Ecol Biogeogr 27:1068-1079

Wootton R (1990) Ecology of teleost fishes. Chapman and Hall, London

Karco-Perello S, Wernberg T, Langlois TJ, Vanderklift MA (2017) Tropicalization strengthens consumer pressure on habitat-forming seaweeds. Sci Rep 7:820

Submitted: July 28, 2020

Accepted: February 1, 2021

Proofs received from author(s): April 13, 2021 